DOI: https://doi.org/10.32839/2304-5809/2021-3-91-46

UDC 371.311 .5

Lakiychuk Olha, Nikitina Nataliia

National Technical University of Ukraine

"Igor Sikorsky Kyiv Polytechnic Institute"

\title{
FEATURES AND PROBLEMATICS OF THE TRANSITION TO THE DISTANCE TEACHING OF THE FOREIGN LANGUAGE
}

Summary. The need to know at least one foreign language is an important and undoubted factor on the path to success of modern man and professional in their field, given that more and more professionals and scientists seek international work, participate in international conferences. Until recently, foreign language classes were quite traditional, namely held in a real classroom, using traditional teaching methods and tools. But given the epidemic situation in 2020, more and more educational institutions are deciding to switch to blended or distance learning. Distance learning in these terms has become a decent attempt to solve the temporal and spatial constraints of the traditional personal learning. Online learning has been the result of the full adoption of technology as part of our lives. In today's world, the term "distance learning" originated due to needs of society and in a short period of time combined all the benefits of the use of modern technologies in the educational process, namely the use of social networking and multimedia along with traditional methods. Distance learning technologies are many new opportunities for teaching foreign languages that allow even more to expand the range of teaching techniques. This paper reports the issues and problems of transition from the traditional type of studying to the distance learning, as well as its features and difficulties that may arise during the transition. The article also reports the prospects for further use of distance learning. This work also highlights the psychological and pedagogical features that may affect the teacher's performance of their pedagogical activities, as well as problems that may arise during the transition to distance learning. The main methods of teaching a foreign language under distance learning are proposed.

Keywords: distance learning, English language, effective training, online training.

Лакійчук О.В., Нікітіна Н.С.

Національний технічний університет України «Київський політехнічний інститут імені Ігоря Сікорського»

\section{ОСОБЛИВОСТІ ТА ПРОБЛЕМАТИКА ПЕРЕХОДУ ДО ДИСТАНЦІЙНОГО ВИКЛАДАННЯ ІНОЗЕМНОЇ МОВИ}

Анотація. Необхідність володіння хоча б однією іноземною мовою є важливим та безсумнівним фрактором на шляху до успіху сучасної людини та професіонала в своїй сфрері, беручи до уваги, що все більше спеціалістів та науковців прагнуть до міжнародної праці, приймають участь у міжнародних конференціях. Донедавна заняття з іноземної мови мали досить традиційний характер, а саме проводились у реальному класі, використовуючи традищійні методи та засоби навчання. Але враховуючи епідемічну обстановку 2020, все більше і більше навчальних закладів вирішуе переходити на змішаний чи дистанційний тип навчання. Всесвітня мережа Інтернет стала на сьогодні основною платформою та посередником у роботі та навчанні в усьому світі. Викладачі та студенти мають змогу отримувати доступ до майже будь якої інформації, що може існувати у мережі Інтернет: тексти, аудіо, відео, підручники, підкасти. За допомогою різноманітних інтернет та Google сервісів викладач може озброїтись безліччю інструментів, що сприятимуть швидшому та ефективнішому засвоєнню матеріалу. Тому саме електронні та мережеві надбання в цей непростий час дали можливість продовжувати навчання, а також, зокрема, вивчати англійську та інші іноземні мови. У цій роботі розкрито питання та проблематика переходу від традиційного типу навчання до дистанційного, а також його особливості та складнощі, що можуть виникати при переході. В статті також розкриті перспективи подальшого використання дистанційного типу навчання. Дана робота також виділяе психологічні та педагогічні особливості, що можуть впливати на виконання викладачем своєї педагогічної діяльності, а також проблеми, що можуть виникати при переході до дистанційного типу навчання. Запропоновані основні методи викладання іноземної мови за умови дистанційного навчання. У статті проаналізовано переваги та недоліки переходу до дистанційного типу навчання, оскільки це може вимагати знання та використання нових технічних засобів, технік, матеріалів, а також швидкого пристосування до нових реалій, як зі сторони викладача, так і зі сторони студента.

Ключові слова: дистанційне навчання, іноземна мова, методи навчання, ефективність викладання.

Droblem statement. The strongest argument

for reforming distance education is a rapidly growing potential for students who do not have access to traditional methods of studying or specialized courses, and their desire to acquire knowledge despite their place of study or financial constraints.

The need of modern society for specialists who are fluent in a foreign language in everyday life and in professional activities, necessitates finding new constructive ideas to solve the problem of optimiza- tion and intensification of foreign language learning, acquisition of new knowledge and improvement of the level of language and speech training [3, p. 39].

The purpose of the article is to reveal the status and prospects of the use of distance learning of English in the training of future specialists.

Analysis of recent research and publications. The problem of using the latest information technologies in the educational process of 
higher educational institutions was dealt with by such domestic and foreign scholars, educators and methodologists, such as J. Underwood, O. Andreev. E. Belova, A. Bernadsky, V. Bespalko, V. Voronina, R. Gurevich, A. Dabagyan, T. Kashitsyn, P. Mayer, V. Soldatkin, V. Tikhomirov, T. Yashchur. The use of the Internet in education was studied by I. Zakharova, E. Polat, V. Popov; Peculiarities of "teacher-student" communication in the process of distance learning were considered by V. Bazhenov and P. Markov.

Main material. Distance learning technologies are represented as many new opportunities for teaching foreign languages that allow expand the range of teaching methods the same way the language laboratories, television and computers have increased the standard class. It is very important to review these distance-learning options to distinguish their ability levels as these systems have different limitations on the learning process. For instance, one-way systems, that use only presentations, have been exposed to criticism, as they did not provide anything other than a video distribution system that could be played by sending videos to the students [4].

Lack of the direct bilateral interaction that characterizes many distance education programs, contradicts the goals of teaching foreign language. However, using this interaction, remote technologies can maintain the integrity of foreign language teaching. Educational strategies that encourage student-teacher dialogue and student autonomy in distance learning situations should be included in the learning process.

Study main material. The purpose of the discipline "Foreign language" is to form the ability of intercultural communication, which has a professional orientation, and is realized on the basis of the formation of intercultural communicative competence. The latter, in its turn, is defined as such a level of mastery of speech, language, socio-cultural and professional subject knowledge, skills and abilities in native and foreign languages, which allows to carry out intercultural communication [1, p. 37].

The main characteristic of computer learning of foreign languages in general as an object of scientific research is its obvious interdisciplinary nature. This is a specific type of problem-oriented research, located between the scope of pure theoretical research, in which knowledge is central, and the scope of informed action, which is dominated by applicability, effectiveness and practical results. The purpose of such research lies in the field of practice, their implementation requires the initial selection and separation of the object of study, its structural components, correlated with subjects of disciplines that study this object. Interdisciplinary essence of the object determines the interdisciplinary paradigm of its study.

Features of psychological and pedagogical conditions of educational implementation process, inherent in one or another form of learning, are largely determined by what real opportunities the student and teacher have for interpersonal communication. For distance learning of foreign languages such feature is the indirect nature of the communication process between teacher and student, which is carried out through computer communications [7, p. 78].
Distance learning provides the possibility of constant and dynamic telecommunications at a distance between student and teacher and students, and the initiative of such communication can come from any of the specified objects of educational process.

It is this feature that allows to make distance learning of foreign languages via the Internet significantly different by form from distance learning, and to some extent to bring it closer to the eye-toeye teaching. It is clear that telecommunication is incapable (for a number of psychological and pedagogical reasons) to be replaced in full by "live" communication [5, p. 128].

As mentioned above, the effectiveness of the use of a tool largely depends on its didactic features. The Internet is a unique environment for learning foreign languages. Enormous informational and didactic opportunities of the computer networks are most effectively used for: educational activities in the process of distance learning courses; independent cognitive activity of students; educational process in and out of class, in particular in the system of additional education.

Learning a foreign language helps to raise the level of general education and qualifications of specialists and is considered as an integral element of the educational system, which is characterized by integrity, autonomy and specificity. Requirements for training specialists of a new type are reflected in the qualification characteristics of the high school graduates (both bachelors and specialists) and provide presence of high culture and knowledge of a foreign language. A graduate of the technical higher educational institution must have spoken language skills, skills of reading, translation and abstracting of texts by specialty.

The motivation for learning foreign languages is a professional need of the student to become a highly qualified specialist with the ability to communicate in a foreign language and obtain information from the latest foreign literature. Therefore, one of the features of this discipline in non-language universities and educational institutions are its professionally-oriented nature [9, p. 79].

Consideration and analysis of the organization of foreign language learning remotely on computer telecommunications has shown that distance learning of foreign languages has its own specifics, due to the fact that it involves learning different types of speech activities. Naturally, for training such speech activities as reading and writing can be largely limited to the online course, as the features of these types of speech activities do not require voluminous graphics and even significant sound accompaniment. However, when learning to speak, pronunciation and listening can not be limited to text files, reliance on sound, as well as the creation of various situations, that stimulate the oral expressions of the subjects are being required, ie there is a need to rely on illustrative material.

The main purpose of teaching a foreign language in higher education is the formation of communicative competence, ie the ability to obtain fairly complete information when reading foreign texts, the ability to understand the interlocutor as well as expressing their opinion, point of view orally and in writing.

Thus, the peculiarity of the subject "foreign language" is that the purpose of learning is not the 
knowledge of the subject itself, that is, of language (language competence), but the process of developing certain skills and abilities of different types of speech activity based on knowledge of the method of activity (communicative competence). According to the theory of activity to teach anyone types of activities are possible only in the course of this activity [6, p. 241].

Distance learning of English using computer and telecommunication technologies should ensure the implementation of such tasks like: formation and development of reading skills with the direct use of Internet materials; improving listening skills based on adapted and authentic audio texts; formation of skills and abilities of translation and abstracting of texts on a specialty; improving the skills of monologue and dialogic speech; expansion of active and passive vocabularies, acquaintance with the vocabulary of modern foreign language, which reflects a certain stage of development of the country's culture, social and political system of society; formation of elements of global thinking (dialogue of cultures); formation of stable motivation of cognitive activity, the need to use a foreign language in real communication; formation of a culture of communication [8, p. 27].

Research in the field of pedagogical technology confirms that the potential of computer distance learning can be most effectively used in the study of foreign languages, which includes discussion, intensive mental activity and collective activity. One of the promising areas of work in the system of foreign distance learning of the languages is an integrated approach to solving the main problems that are combined in this system: a set of technologies with high didactic potential and telecommunication technology; computer learning of foreign languages, multimedia technology and methods of intensive foreign language learning [11].
A review of the experience of using new information technologies in foreign language teaching has shown that foreign teaching experience is much ahead of the domestic. An analysis of the available information technology software in the field of English language teaching revealed that selected didactic computer programs are adequate to the developed models teaching. There are variants of didactic models of distance learning of the foreign languages with the use of information technology significantly affect the quality of teaching foreign languages to the students from higher educational institutions.

Conclusions. It is determined that distance learning of a foreign language is gaining popularity in educational space. Further development of information technologies, integration of Ukrainian distance education into the world educational community, the inevitable virtualization of universities operating in the field of distance education will lead to distance learning of foreign languages to compulsory study not only in the context of independent discipline, but also in combination with different courses.

Thus, having analyzed the features of the transition to distance learning, among the difficulties we can highlight the following:

- selecting, launching and adapting the learning platform;

- adapting curricula;

- monitoring of learning outcomes;

- teacher training in digital technologies;

- the need for a new structure of work organization;

- unwillingness of teachers and students to distance learning.

Concluding, one must say that these ones and some other problems should be solved in the process of transition to the distance learning to gain the highest level of effectiveness while teaching any foreign language.

\section{References:}

1. Andreev A.A. (2001) Kompyuternye i telekommunikaczionnye tekhnologii v sfere obrazovaniya [Computer and telecommunication technologies in the sphere of education]. Technology school, pp. 32-40.

2. Vishnevskaya G.V. (2011). Vnedrenie distanczionnykh tekhnologij v proczess obucheniya inostrannomu yazyku studentov-zaochnikov neyazykovykh vuzov [The introduction of distance technologies in the process of teaching a foreign language to part-time students of non-linguistic universities]. V.G. Berlinskiy PGPU News, no. 24, pp. 589-592.

3. Dishleva Yu.V. (2008) Rol ta miscze suchasnikh metodik u vivchenni anglijskoyi movi v kursi distanczijnogo navchannya [The role and place of modern methods in the study of English in the course of distance learning. Teaching languages in higher education at the present stage. Cross-curricular links. Scientific research. Experience. Search], vol. 13, pp. 35-41.

4. Konczepcziya rozvitku distanczijnoyi osviti v Ukrayini[The concept of development of the distance learning in Ukraine]. URL: http://www.osvita.org.ua/distance/pravo/00.html (accessed 15 February 2021).

5. Kukharenko V.M. (2007) Distanczijne navchannya: encziklopedichne vidannya [Distance learning: encyclopedic edition]: educational and methodical manual. Kyiv, $128 \mathrm{p.}$

6. Sokolov A.V. (1996) Vvedenie $\mathrm{v}$ teoriyu soczialnoj kommunikaczii [Introduction to the theory of social communication]. SPb., $327 \mathrm{p}$.

7. Homberg B. (1977) Distance Education: A Survey and Bibliography. L.: Kogan Page, 234 p.

8. Keengwe J. (2012) Student and Instructor Satisfaction with E-learning Tools in Online Learning Environments. International Journal of Information and Communication Technology Education, 8(1), pp. 76-86.

9. Oxford University Press (2020) Distance learning. Oxford Advanced Learner's Dictionary. URL: https://www.oxfordlearnersdictionaries.com/definition/english/distance-learning? $q=$ distance+learning (accessed 18 February 2021).

10. University of the people (2021) What is Distance Learning? The Benefits of Studying Remotely. URL: https://www.uopeople.edu/blog/what-is-distance-learning/ (accessed 18 February 2021).

\section{Список літератури:}

1. Андреев А.А Компьютерные и телекоммуникационные технологии в сфере образования. Шк. технол., 2001. C. 32-40.

2. Вишневская Г.В. Внедрение дистанционных технологий в процесс обучения иностранному языку студентовзаочников неязыковых вузов. Известия ПГПУ ил. В. Г. Белинского. 2011. Випуск 24. С. 589-592. 
3. Дишлева Ю.В. Роль та місце сучасних методик у вивченні англійської мови в курсі дистанційного навчання. Викладання мов у вищих навчальних закладах освіти на сучасному етапі. Міжпредметні зв'язки. Наукові дослідження. Досвід. Пошуки. 2008. Вип. 13. С. 35-41.

4. Концепція розвитку дистанційної освіти в Україні. Київ, 2020. URL: http://www.osvita.org.ua/distance/ pravo/00.html (дата звернення: 15.02.2021).

5. Кухаренко В.М. Дистанційне навчання: енциклопедичне видання : навч.-метод. посіб. Київ, 2007.128 с.

6. Соколов А.В. Введение в теорию социальной коммуникации. СПб., 1996. 327 с.

7. Homberg B. Distance Education: A Survey and Bibliography / B. Homberg. L.: Kogan Page, 1977. 234 p.

8. Keengwe J. Student and Instructor Satisfaction with E-learning Tools in Online Learning Environments. International Journal of Information and Communication Technology Education. 2012. 8(1). Pp. 76-86.

9. Oxford University Press (2020). Distance learning. Oxford Advanced Learner's Dictionary. URL: https://www.oxfordlearnersdictionaries.com/definition/english/distance-learning? $\mathrm{q}=$ distance+learning (дата звернення: 18.02.2021).

10. University of the people (2021). What is Distance Learning? The Benefits of Studying Remotely. URL: https://www.uopeople.edu/blog/what-is-distance-learning/ (дата звернення: 18.02.2021). 